\title{
A Sensitive, Quantitative Assay for Measurement of Allele-specific Transcripts Differing by a Single Nucleotide
}

\author{
Judith Singer-Sam, Jeanne M. LeBon, \\ Aihua Dai, and Arthur D. Riggs \\ Biology Division, Beckman Research Institute of the City of Hope, \\ Duarte, CA 91010
}

\begin{abstract}
We have found that the single nucleotide primer extension assay, a PCR-based assay currently used qualitatively to measure allelic differences in DNA, can be used quantitatively to measure allelespecific transcripts differing by only a single nucleotide. We show that total RNA containing the Pgk-1a transcript can be specifically detected even in a 1000 -fold excess of RNA containing the Pgk-1b transcript.
\end{abstract}

S everal amplification-based assays have been described recently for the detection of allelic differences in DNA. ${ }^{(1-5)}$ The assays have been used qualitatively, showing an all-or-none response, depending upon the presence or absence of a given allele. For some studies of gene regulation, however, it is important to quantitate the amount of RNA synthesized from a given allele. This is true, for example, for studies on $\mathrm{X}$ chromosome inactivation, where changes in relative amounts of transcripts from two alleles of an X-linked gene may be used to probe differences in the activity of the $\mathrm{X}$ chromosome. In addition, an assay sensitive enough to detect quantitatively RNA from an allele being expressed at a relatively low level, or DNA present in less than single-copy amounts, should aid experiments in many areas, for example, work on the mechanism of parental imprinting and gene rearrangement.

After investigating several methods, we have found that single-nucleotide primer extension (SNuPE) ${ }^{(4)}$ is the assay most readily adaptable for the quantitative measurement of allelespecific RNA or DNA. SNuPE involves two steps. The first step is the amplification by PCR of a segment containing the allelic difference; the second step, which results in allelic specificity, is the enzymatic extension by one nucleotide of a primer that is complementary to one strand of the amplified product just $5^{\prime}$ to the position of the allelic difference ${ }^{(4)}$ (see Fig. 1). In a given reaction, only the deoxynucleotide triphosphate specific for one of the alleles is used, allowing each allele to be probed separately. We report here that the SNuPE assay is quantitative over a wide range, and that allele-specific transcripts differing by only a $\mathrm{C} \rightarrow \mathrm{A}$ transversion can readily be detected, even when the predominant allele is present in 1000-fold excess.

\section{METHODS}

RT-PCR amplification and isolation of amplified products

A 309-bp fragment corresponding to nucleotides $442-750$ of the published sequence of mouse Pgk-1 $\mathrm{CDNA}^{(6)}$ was amplified by use of the primers GTAAAGGCCATTCCACCACCAA (upstream primer) and AGCTGAGCCGGC CAAAATTGAT (downstream primer). Liver RNA was isolated by the use of RNAzol B (Cinna Biotecx) from C57/BL6J mice homozygous for either the Pgk- $1^{\mathrm{a}}$ allele (Jackson Lab, ME) or the Pgk- $1^{b}$ allele (Simonson Lab, CA). The purified RNA was diluted in buffer [Tris- $\mathrm{HCl}, \mathrm{pH} 8,1 \mathrm{~mm}$; EDTA, $0.1 \mathrm{~mm}$; $\mathrm{NaCl}, 10 \mathrm{~mm}$; tRNA, $1 \mu \mathrm{g} / \mathrm{ml}$; RNasin, 1 $\mathrm{U} / \mu \mathrm{l}$ (Promega)], and RT-PCR was done according to the protocol supplied by Cetus. Briefly, RNA (1-2 ng) was reverse-transcribed in $10 \mathrm{mM}$ Tris- $\mathrm{HCl}$ (pH 8.3), $50 \mathrm{mM} \mathrm{KCl}, 5 \mathrm{mM} \mathrm{MgCl}_{2}, 1$ $\mathrm{mM} \mathrm{dXTPs}$, and $2 \mathrm{U} / \mu \mathrm{l}$ RNasin in a final volume of $20 \mu \mathrm{l}$. The downstream primer was present at $1 \mu \mathrm{M}$, and Moloney murine leukemia virus reverse transcriptase (Mo-MLV RT) (BRL) was added to $2.5 \mathrm{U} / \mu \mathrm{l}$. After in- 
cubation at $42^{\circ} \mathrm{C}$ for $15 \mathrm{~min}$, the reaction was stopped by heating to $99^{\circ} \mathrm{C}$ for $5 \mathrm{~min}$. The reaction was then diluted to $100 \mu \mathrm{l}$ with a master mix so that the final concentrations of ingredients were: $10 \mathrm{mM}$ Tris- $\mathrm{HCl}(\mathrm{pH}$ 8.3), $50 \mathrm{~mm} \mathrm{KCl}, 2 \mathrm{~mm} \mathrm{MgCl}_{2}, 200 \mu \mathrm{M}$ dXTPs, $0.2 \mu \mathrm{M}$ downstream and upstream primers, and 2.5 units/reaction of Amplitaq polymerase (Cetus). PCR was then done in a Gene Machine II thermal cycler (USA/Scientific Plastics, FL) $\left[95^{\circ} \mathrm{C}, 1 \mathrm{~min}(3 \mathrm{~min}\right.$ for the first cycle) followed by $59^{\circ} \mathrm{C}, 1 \mathrm{~min}$ for 40 cycles].

After phenol/chloroform extraction and ethanol precipitation, the amplified products were subjected to agarose gel electrophoresis in TAE buffer. ${ }^{(7)}$ The 309-bp bands were extracted by use of Gelase (Epicentre Technologies, Madison, WI), followed by ethanol precipitation. DNA was resuspended in TE (10 mM Tris- $\mathrm{HCl}, \mathrm{pH} 8,1 \mathrm{~mm}$ EDTA), and the approximate concentration was determined by ethidium bromide staining after gel electrophoresis of an aliquot.

\section{The SNuPE assay and quantitation}

The SNuPE assay was done essentially as described. ${ }^{(4)}$ The reaction mix contained, in a total volume of $10 \mu \mathrm{l}, 1 \mathrm{x}$ buffer (10 mm Tris- $\mathrm{HCl}, \mathrm{pH} 8.3,50 \mathrm{~mm}$ $\mathrm{KCl}, 5 \mathrm{mM} \mathrm{MgCl}_{2} 0.001 \%$ gelatin), 1 $\mu \mathrm{M}$ pgk471 primer (TCCGAGCCTCACT GTCCA), 0.75 units of Taq polymerase (Cetus), $2 \mu \mathrm{Ci}$ of $\left[{ }^{32} \mathrm{P}\right] \mathrm{dCTP}$ or [32P]dATP, and amplified DNA fragment ( $10 \mathrm{ng} /$ reaction). [ $\left.{ }^{32} \mathrm{P}\right] \mathrm{dCTP}$ or [ $\left.{ }^{32} \mathrm{P}\right] \mathrm{dATP}(3000 \mathrm{Ci} / \mathrm{mmole}, 10 \mu \mathrm{Ci} / \mu \mathrm{l})$ was diluted fivefold in $\mathrm{H}_{2} \mathrm{O}$, and $1 \mu \mathrm{l}$ was added to each tube just prior to incubation; all other ingredients were added to the templates as part of a master mix. The primer was heated briefly to $90^{\circ} \mathrm{C}$ prior to addition to the master mix to avoid artifacts as a result of repeated freeze-thawing. The samples were incubated at $95^{\circ} \mathrm{C}$ for 1 $\min , 42^{\circ} \mathrm{C}$ for $2 \mathrm{~min}$, and $72^{\circ} \mathrm{C}$ for 1 min for one cycle in an Ericomp thermal cycler. After electrophoresis of the samples on a $15 \%$ denaturing polyacrylamide gel, the radioactivity in each band was determined by use of the AMBIS Radioisotope Scanning System II (Automated Microbiology System, Inc.).

\section{RESULTS}

Shown in Figure 1 is an outline of the adaptation of the SNuPE assay for quantitative measurement of allelespecific transcripts, using the Pgk- I $^{\text {a }}$ and Pgk- ${ }^{b}$ alleles as a model system. As indicated schematically, the two alleles differ by one base at position 490 of the cDNA sequence, ${ }^{(8)} \mathrm{C}$ versus $\mathrm{A}$ for the $\mathrm{Pgk}-1^{\mathrm{a}}$ and $\mathrm{Pgk}-1^{\mathrm{b}}$ alleles, respectively.

Total RNA is amplified by RT-PCR; the amplified product is then gelpurified, and the SNuPE assay is done using the appropriate 32 P-labeled triphosphate. To detect the Pgk- $1^{a}$ allele, $\left[{ }^{32} \mathrm{P}\right] \mathrm{dCTP}$ is added; for the Pgk- ${ }^{\mathrm{b}}$ allele, $\left[{ }^{32} \mathrm{P}\right] \mathrm{dATP}$ is added. The ratio of the signals resulting from the two separate reactions should be proportional to the relative amount of each transcript initially present.

As a first step in development of the assay, we demonstrated that allelic variants of the Pgk-1 gene were detectable by the SNuPE method. Amplified products from either the Pgk- $1^{\mathrm{a}}$ or Pgk- $1^{b}$ alleles were used for the SNuPE assay, with results shown in Figure 2. A very clear allele-specific signal is seen (cf. lanes 1 vs. 2 , and lanes 4 vs. 5). Particularly striking is the apparent absence of background due to primer extension of the "incorrect" allele (Fig. 2, lanes 1 and 5).

We next did a mixing experiment to determine whether the relative amounts of Pgk- $1^{\mathrm{a}}$ and Pgk-1 ${ }^{\mathrm{b}}$ RNA do in fact affect the signal. Pgk-1 ${ }^{\mathrm{a}}$ - or Pgk$1^{\text {b }}$-containing RNA was purified from homozygous mice (see Methods) and

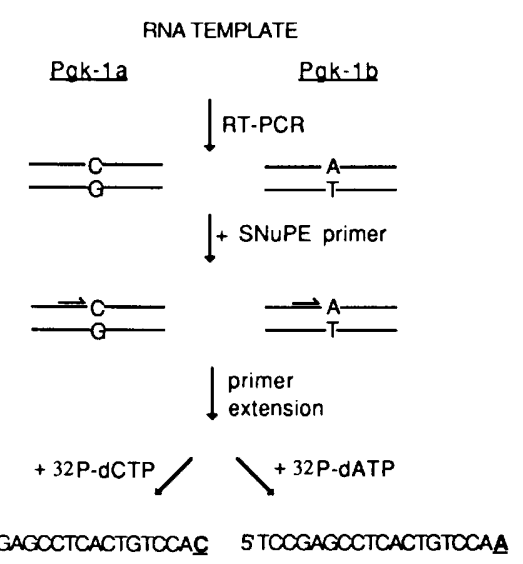

FIGURE 1 Schematic outline of the RT-PCR SNuPE assay. Pgk- $1^{a}$ and Pgk-1 $1^{b}$ are the two alleles of the Pgk-1 gene (see text.)

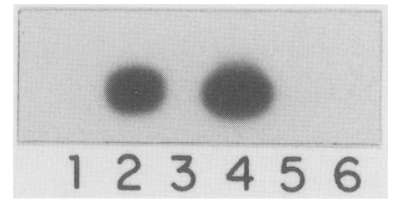

FIGURE 2 Autoradiogram showing detection of the Pgk-1 ${ }^{\mathrm{a}}$ and Pgk-1 ${ }^{\mathrm{b}}$ alleles. Template DNA consisted of $10 \mathrm{ng}$ of PCR-amplified products of the Pgk- $1^{\mathrm{a}}$ or $\mathrm{Pgk}-\mathrm{1}^{\mathrm{b}}$ alleles, containing either $\mathrm{C}$ or $\mathrm{A}$, respectively, at position 489 of the cDNA sequence. ${ }^{(6)}$ Extension of a primer with either [ $\left.{ }^{32} \mathrm{P}\right] \mathrm{dATP}$ or $\left[{ }^{32} \mathrm{P}\right] \mathrm{dCTP}$, followed by gel electrophoresis, was done as indicated in Methods. The gel was then exposed to XAR-5 film for $2 \mathrm{hr}$ at $4^{\circ} \mathrm{C}$. (Lane 1) Pgk- $1^{\mathrm{a}}$ template, $\left[{ }^{32} \mathrm{P}\right] \mathrm{dATP}$; (lane 2) Pgk-1 ${ }^{\mathrm{b}}$ template, $\left.{ }^{32} \mathrm{P}\right] \mathrm{dATP}$; (lane 3) no template added, [ $\left.{ }^{32} \mathrm{P}\right] \mathrm{dATP}$; (lane 4) Pgk- $1^{\mathrm{a}}$ template, $\left.{ }^{32} \mathrm{P}\right] \mathrm{dCTP}$; (lane 5) Pgk- ${ }^{\mathrm{b}}$ template, $\left[^{32} \mathrm{P}\right] \mathrm{dCTP} ;($ lane 6) no template added, $\left[{ }^{32}\right.$ P]dCTP.

then mixed as shown in the legend to Figure 3. After RT-PCR and the SNuPE assay, the results shown in Figures 3 and 4 were obtained: Figure $3 \mathrm{~A}$ shows that when increasing amounts of Pgk- $1^{\mathrm{a}}$-containing RNA are added, the Pgk- $1^{\mathrm{a}}$-specific signal increases. Figure $3 \mathrm{~B}$, by contrast, shows that the Pgk- $1^{\mathrm{b}}$. specific signal remains nearly constant, reflecting the relatively high amount present in each reaction. There is some reduction in signal in lanes 7 and 8 of Figure $3 \mathrm{~B}$, as in these samples $23 \%$ and $50 \%$, respectively, of the $10 \mathrm{ng}$ of amplified product assayed is due to the Pgk- $1^{\mathrm{a}}$ allele (see legend to Fig. 3). Figure 4 shows the ratio of the Pgk- $1^{\mathrm{a}}$ specific to the Pgk-1 ${ }^{\mathrm{b}}$-specific signal plotted versus the relative amount of RNA in the initial RT-PCR reaction. The proportional relationship is seen clearly (correlation, 0.997), even when the ratio of $\mathrm{Pgk}-1^{\mathrm{a}}$ to $\mathrm{Pgk}-1^{\mathrm{b}} \mathrm{RNA}$ is 0.001 .

These results demonstrate two aspects of the assay: (1) They confirm that RT-PCR of two nearly identical RNAs with one set of primers amplifying both templates results in quantitative amplification; (2) they show that the SNuPE assay is quantitative and allows allele-specific discrimination over a wide range of relative concentrations of each transcript.

To determine the reproducibility of the assay, varying amounts of the amplified product of the $\mathrm{Pgk}-\mathrm{I}^{\mathrm{a}}$ allele were mixed with $10 \mathrm{ng}$ of the Pgk-1 ${ }^{\mathrm{b}}$ 


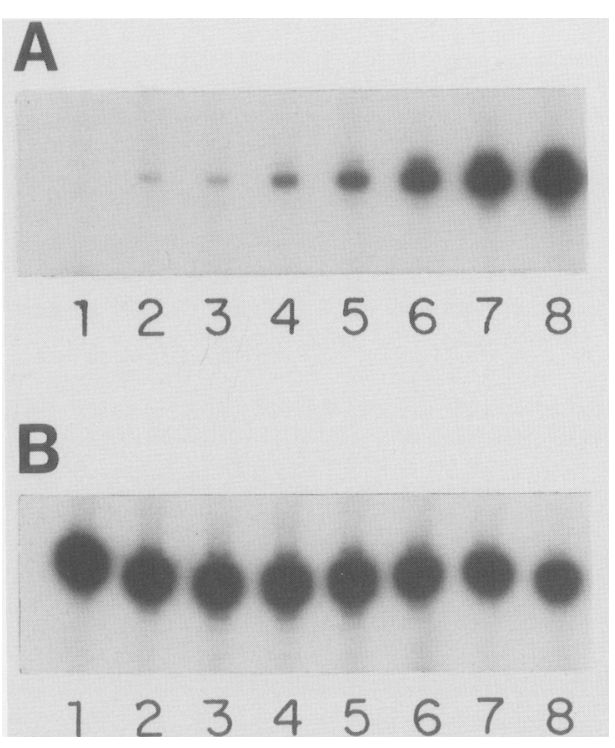

FIGURE 3 Reconstruction experiment. One nanogram of total liver RNA from a mouse homozygous for the Pgk-1 ${ }^{\mathrm{b}}$ allele was mixed with the indicated amounts of RNA from a Pgk-1 ${ }^{\text {a }}$ homozygote. RT-PCR was done, and then $10 \mathrm{ng}$ of the gel-purified PCR product was used for the SNuPE assay with either $\left[{ }^{32} \mathrm{P}\right] \mathrm{dCTP}(A)$ or $\left[{ }^{32} \mathrm{P}\right] \mathrm{dATP}(B)$. Amount of Pgk-1 ${ }^{\mathrm{a}}$-containing RNA added: (lane 1) none; (lane 2) $0.001 \mathrm{ng}$; (lane 3) $0.003 \mathrm{ng}$; (lane 4) $0.01 \mathrm{ng}$; (lane 5) $0.03 \mathrm{ng}$; (lane 6) $0.1 \mathrm{ng}$; (lane 7) $0.3 \mathrm{ng}$; (lane 8) 1 ng.

product. When the results of three experiments were analyzed, a correlation was found similar to that described for Figure 4 (intraclass correlation coefficient, 0.992). The error seems to increase somewhat with a decreasing amount of the allele being measured, the percent standard deviation ranging from $10 \%$ when $3 \mathrm{ng}$ of the Pgk-1 ${ }^{\mathrm{a}}$ amplified fragment is added to $30 \%$ when only $0.01 \mathrm{ng}$ is added. Thus, two- to threefold differences are measurable, even when the Pgk- $1^{\mathrm{a}}$ allele is present as $0.1 \%$ of the total.

To determine the general applicability of the assay, we did a reconstruction experiment with templates allowing the detection of $\mathrm{A} / \mathrm{C}, \mathrm{G} / \mathrm{C}$, and $\mathrm{C} / \mathrm{G}$ ratios. Although the background was sometimes higher than that reproducibly seen for C/A measurement, in all cases a quantifiable signal was obtained when the allele being measured was at least $1 \%$ of the total. Our findings, together with the previous data on $\mathrm{G} / \mathrm{C}$ and $\mathrm{C} / \mathrm{T}$ mismatches, ${ }^{(4)}$ suggest that the assay should be applicable to the quantitative detection of any mismatch.

\section{DISCUSSION}

The SNuPE assay provides convenience, quantifiability, and very sensitive allele-specific discrimination. Other assays have various drawbacks for allele-specific quantitative measurement. The ligation amplification reaction, ${ }^{(9)}$ in which a labeled primer is ligated to form a higher-molecularweight product only if the correct complementary base is present on the template, is difficult to quantitate (our unpublished results and R.B. Wallace, pers. comm.). Competition hybridization, ${ }^{(10)}$ hybridization of PCR products to an oligonucleotide probe in the presence of an excess of unlabeled oligonucleotide specific for the other allele, can be used quantitatively. However, at least for Pgk- $1^{a} / 1^{b}$, even under optimal conditions, allele-specific discrimination is only possible when one is measuring intermediate levels of one allele relative to another $(>1 \%)$ (our unpublished data). Temperature gradient or other denaturing gels are sequence dependent and did not work for our sequence (unpubl.); furthermore, even when they are used successfully, the results do not appear to be quantitative. ${ }^{(1)}$ Because the SNuPE assay depends on a critically specific event in DNA synthesis-nucleotide selection by a template-bound DNA

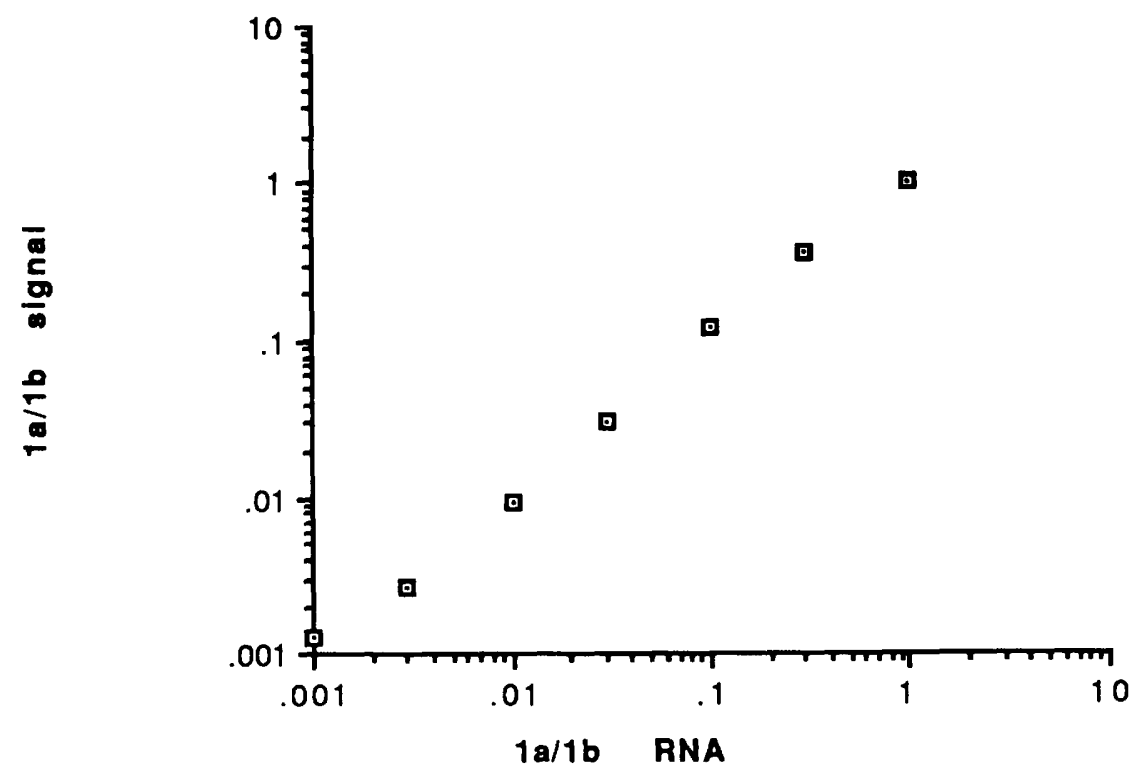

FICURE 4 Quantitation of the RT-PCR SNuPE experiment shown in Fig. 3. polymerase-the assay is especially useful for sensitive quantitative measurement.

The quantitative use of the SNuPe assay relies on the quantifiability of PCR. Several groups have now shown that the inclusion in PCR reactions of a control template differing by a single base pair or by a small deletion from the template being measured allows quantitative measurement of the template. ${ }^{(11-13)}$ The key element is that both templates are amplified by the same primer set, so that tube-to-tube variation affects amplification of both experimental and control templates equally. Fortunately, when allelic differences are being measured, one allele automatically serves as an internal control for amplification of the other. In the case of allele-specific detection of RNA, quantitative RT-PCR should be particularly accurate, since the "control" RNA naturally present compensates for tube-to-tube variation in the efficiency of reverse transcription as well as PCR.

Quantitative SNuPE should also provide an accurate system for detecting the absolute amount of transcript present. Restriction enzymes have previously been used after RT-PCR ${ }^{(12)}$ to compare the amount of amplified fragment produced from the RNA of interest to the amount co-amplified from a known amount of standard RNA (or DNA) differing by 1 base at an internal 
restriction site. ${ }^{(12)}$ If quantitative SNuPE is used, there is greater flexibility in the choice of the added standard template and in the range of detectability, which would no longer be limited by uncertainty over completeness of cutting by a restriction enzyme.

In the experiment described in Figure $3,1 \mathrm{ng}$ of Pgk-1 $1^{\mathrm{b}}$-containing mouse liver RNA was used. The maximum estimate of abundance of Pgk-1 transcripts in mouse liver is $0.2 \%$ of total mRNA or about 20,000 copies per cell. Therefore, if one assumes that $10 \%$ of liver RNA is poly(A) ${ }^{+}$mRNA, $1 \mathrm{ng}$ of total RNA should correspond to $-200,000$ molecules of Pgk- $1^{\mathrm{b}}$ mRNA. Because we can detect 0.001 ng of Pgk$1^{\mathrm{a}}$-containing RNA in this mix, we estimate that $\sim 200$ molecules of allelespecific RNA are detectable. Thus, for a moderately expressed gene such as Pgk-1, a single cell provides a sufficient number of RNA molecules for detection of an allelic variant present as $1 \%$ of the predominant allelic transcript.

The assay described here can be sensitive enough to measure quantitatively changes in $0.1 \%$ of a transcript population. This sensitivity is adequate for the study of either allele-specific gene regulation or transcriptional changes occurring in a minority of cells (e.g., RNA splicing events). The assay can be used equally well for the quantitative assay of changes in DNA. For many such studies, for example gene rearrangements in a population of $T$ or B cells, sensitivity of the assay is adequate as described. It is possible that the detection limit can be lowered by use of a DNA polymerase with a lower rate of misincorporation than Taq polymerase. In that case, the assay would also be suitable for studies of mutations and other rare events.

\section{ACKNOWLEDGMENT}

This work was supported by National Institutes of Health grant RO1 AG08196.

\section{REFERENCES}

1. Bourguin, A., R. Tung, N. Galili, and J. Sklar. 1990. Rapid, nonradioactive detection of clonal T-cell receptor gene rearrangements in lymphoid neoplasms. Proc. Natl. Acad. Sci. 87: 8536-8540.
2. Myers, R.M., T. Maniatis, and L.S. Lerman. 1987. Detection and localization of single base changes by denaturing gradient gel electrophoresis. Methods Enzymol. 155: 501-527.

3. Nozari, G., S. Rahbar, and R.B. Wallace. 1986. Discrimination among the transcripts of the allelic human $\beta$ globin genes, $\beta^{A}, \beta^{S}$ and $\beta^{C}$ using oligodeoxynuceotide hybridization probes. Gene 43: 23-28.

4. Kuppuswamy, M.N., J.W. Hoffmann, C.K. Kasper, S.G. Spitzer, S.L. Groce, and S.P. Bajaj. 1991. Single nucleotide primer extension to detect genetic diseases: Experimental application to hemophilia B (factor IX) and cystic fibrosis genes. Proc. Natl. Acad. Sci. 88: 1143-1147.

5. Wu, D.Y., L. Ugozzoli, B.K. Pal, and R.B. Wallace. 1989. Allele-specific enzymatic amplification of $\beta$-globin genomic DNA for diagnosis of sickle cell anemia. Proc. Natl. Acad. Sci. 86: 2757-2760.

6. Mori, N., J. Singer-Sam, C.-Y. Lee, and A.D. Riggs. 1986. The nucleotide sequence of a cDNA clone containing the entire coding region for mouse $\mathrm{X}$ chromosome-linked phosphoglycerate kinase. Gene 45: 275-280.

7. Maniatis, T., E.F. Fritsch, and J. Sambrook. 1982. Molecular cloning: $A$ laboratory manual. Cold Spring Harbor Laboratory, Cold Spring Harbor, New York.

8. Boer, P.H., H. Potten, C.N. Adra, K. Jardine, G. Mullhofer, and M.W. McBurney. 1990. Polymorphisms in the coding and noncoding regions of murine Pgk-1 alleles. Biochem. Genet. 28: 299-308.

9. Wu, D.Y. and R.B. Wallace. 1989. The ligation amplification reaction (LAR)amplification of specific DNA sequences using sequential rounds of template-dependent ligation. Genomics 4: 560-569.

10. Wu, D.Y., G. Nozari, M. Schöld, B.J. Conner, and R.B. Wallace. 1989. Direct analysis of single nucleotide variation in human DNA and RNA using in situ dot hybridization. DNA 8: $135-142$.

11. Becker-André, M. and K. Hahlbrock. 1989. Absolute mRNA quantification using the polymerase chain reaction (PCR). A novel approach by a PCR aided transcript titration assay (PATTY). Nucleic Acids Res. 17:
9437-9446.

12. Gilliland, G., S. Perrin, and H.F. Bunn. 1990. Competitive PCR for quantitation of mRNA. In $P C R$ Protocols (ed. M.A. Innis, D.H Gelfand, J.J. Sninsky, and T.J. White), pp. 60-69. Academic Press, New York.

13. Singer-Sam, J., J.M. LeBon, R.L. Tanguay, and A.D. Riggs. 1990. A quantitative Hpa II-PCR assay to measure methylation of DNA from a small number of cells. Nucleic Acids Res. 18: 687.

Received August 26, 1991; accepted in revised form November 19, 1991. 


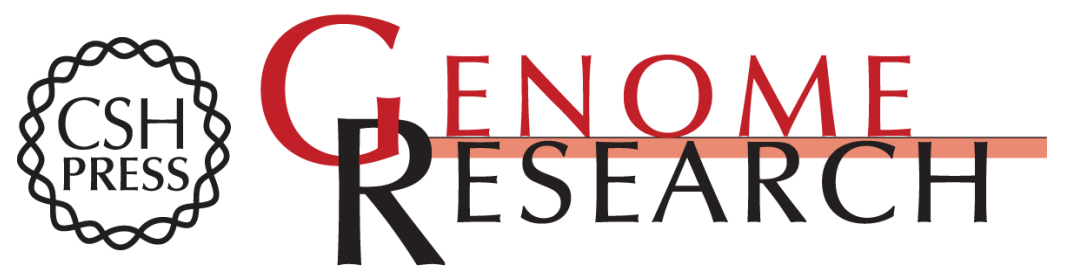

\section{A sensitive, quantitative assay for measurement of allele-specific transcripts differing by a single nucleotide.}

J Singer-Sam, J M LeBon, A Dai, et al.

Genome Res. 1992 1: 160-163

Access the most recent version at doi:10.1101/gr.1.3.160

References This article cites 11 articles, 3 of which can be accessed free at:

http://genome.cshlp.org/content/1/3/160.full.html\#ref-list-1

\section{License}

Email Alerting Receive free email alerts when new articles cite this article - sign up in the box at the Service top right corner of the article or click here.

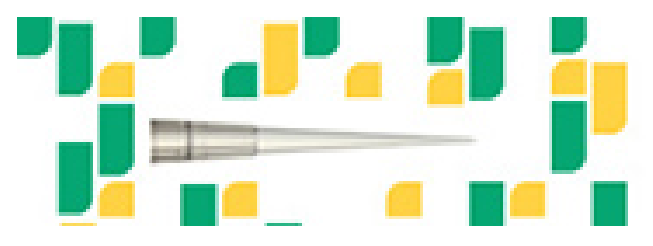

To subscribe to Genome Research go to: https://genome.cshlp.org/subscriptions 